\title{
Sakubitril/valsartan'ın bazal NTproNP düzeylerine göre etkinliğinde fark olur mu?
}

\author{
(D) Dr. Hüseyin Altuğ Çakmak
}

Mustafakemalpaşa Devlet Hastanesi, Kardiyoloji Kliniği, Bursa

Natriüretik peptidler (NP) olan B-tipi natriüretik peptid (BNP) ve N-terminal pro-B tipi natriüretik peptid (NT-proBNP)'lerin KY hastalarındaki tanısal ve prognostik değeri önceki çalışmalarda gösterilmiştir. ${ }^{[1,2]}$ Ayrıca, takip sırasındaki NP seviyelerindeki azalma daha düşük mortalite ve morbidite oranı ile ilişkili bulunurken; artan NP değerleri ise kötü prognoz göstergesi olarak bildirilmiştir. ${ }^{[3-5]}$ Bunun yanında, bazal NP seviyelerindeki değişimlerin tedavi başarısının etkinliğini değerlendirmede ki rolü hakkında, yetersiz hasta popülasyonu, düşük olay oranı, tedavi stratejilerinin etkinliği, NP ölçüm sıklığı, takip süresi ve NP değerlerinde geniş farklılıklar nedeniyle farklı çalışmalarda farklı sonuçlar rapor edilmiştir. ${ }^{[6-8]} \mathrm{Bu}$ anlamda PARADIGM-HF çalışması geniş hasta popülasyonu, önemli derecede yüksek olay oranı, tedavi stratejilerinin etkinliği, NP ölçüm sıklığı yeterli takip süresi gibi sebeplerden ötürü önceki yayınlanan çalışmaların kısıtlılı̆̆ını gidermiştir. ${ }^{[4]} \mathrm{Bu}$ çalışmada NP dahil etme kriterleri açısından BNP $\geq 150 \mathrm{pg} / \mathrm{ml}$ (NTproBNP $\geq 600 \mathrm{pg} / \mathrm{ml}$ ) veya son 12 ay içerisinde kalp yetmezliğinden hastaneye yatmış hastalarda BNP $\geq 100 \mathrm{pg} / \mathrm{ml}$ (NT-proBNP $\geq 400 \mathrm{pg} / \mathrm{ml}$ ) olan hastalar çalışmaya dahil edilmiştir. Primer analizler, plazma NT-proBNP değerindeki değişikliklerin 5 farklı zamanda ölçümü yapılarak sunulmuştur (run-in öncesi bazal, enalapril run-in sonrası, randomizasyonda, randomizasyon sonras1 1. ayda ve 8. ayda). Ayrica, her bir spesifik zaman noktasında bazale göre NT-proBNP değerlerindeki değişiklik ve tedavilerin NT-proBNP seviyeleri üzerine olan etkileri değerlendirilmiştir. Genel sonuçlara göre bazal median NT-proBNP değerlerinin hem üzerinde ve hem de altındaki değerlere sahip olgularda primer sonlanım noktaları sakubitril-valsartan grubunda enalaprile göre anlamlı olarak daha düşük saptanmıştır. NP düzeylerine ilişkin yapılan bir başka analizde, bazal ve 1. ay NT-proBNP değerleri 4 kategoriye ayrıldı [bazal ve 1. ayda NTproBNP $\leq 1000 \mathrm{pg} / \mathrm{ml}$ (düşük-düşük), bazal ve 1 . ayda NT-proBNP $\geq 1000 \mathrm{pg} / \mathrm{ml}$ (yüksek-yüksek), bazal NTproBNP $>1000 \mathrm{pg} / \mathrm{ml}$ ve 1 . ayda $\leq 1000 \mathrm{pg} / \mathrm{ml}$ (yüksek-düşük) ve bazal NT-proBNP $\leq 1000 \mathrm{pg} / \mathrm{ml}$ ve 1 . ayda $>1000$ pg/ml (düşük-yüksek)]. Randomizasyondan 1 ay sonra; bazalde yüksek NT-proBNP'si olanların \%24'ü $\leq 1000$ pg/ml olup, $>1000$ pg/ml olanlara kıyasla primer sonlanım noktasında \%59 düşüş saptandı. Primer olay sıklığındaki benzer düşüş oranları bazalde NT-proBNP'si $>1000 \mathrm{pg} / \mathrm{ml}$ olan ve 1 . ayda NT-proBNP'si $\leq 750 \mathrm{pg} / \mathrm{ml}$ ve $\leq 500 \mathrm{pg} / \mathrm{ml}$ olanlarda da gözlendi. Benzer gözlemler NT-proBNP'de bazal değerinden yüzdesel olarak azalmalar olduğunda da saptand. Kategorik (subgrup) NT-proBNP analizlerinde de beklendiği üzere en düşük primer olay sıklığ1 düşük-düşük grupta; en yüksek primer olay sıklığı ise yüksek-yüksek grupta gözlendi. Diğer alt gruplarda ise primer olay sıklığı orta düzeyde görüldü. Sürekli analizlerde ise; bazal değerden 1. ay sonuna kadar olan zamandaki değişiklik, sonraki olayların önemli bağımsız öngördürücüsü olarak saptandı. Yani NTproBNP'nin bazalden 1. aydaki değerine yükselme görüldükçe primer olay oranı artarken; tersi de doğru olarak bulundu. Ayrica, bazal NT-pro-BNP düzeltildikten sonra, 1. aydaki NT-pro-BNP değeri 2 katına çıktığında hazard ratio (HR) 1.46 olurken, yarı değere indiğinde ise 0.68 olarak bulundu.

Sakubitril-valsartan ve enalapril tedavilerinin bazal NT-proBNP düzeylerine göre etkinliğine bakıldiğında (Şekil 1); ortalama NT-proBNP düzeyinin enalapril run-in kolunda önemli oranda değişmediği ancak sakubitril-valsartan run-in kolunda önemli oranda azaldığı görüldü. Randomizasyon sonrası 1 . ayda NT-proBNP düzeylerinin sakubitril-valsartan kolunda enalapril koluna göre anlamlı derecede azaldığı saptandı (Şekil 1b). NT-proBNP değeri $\leq 1000$ 

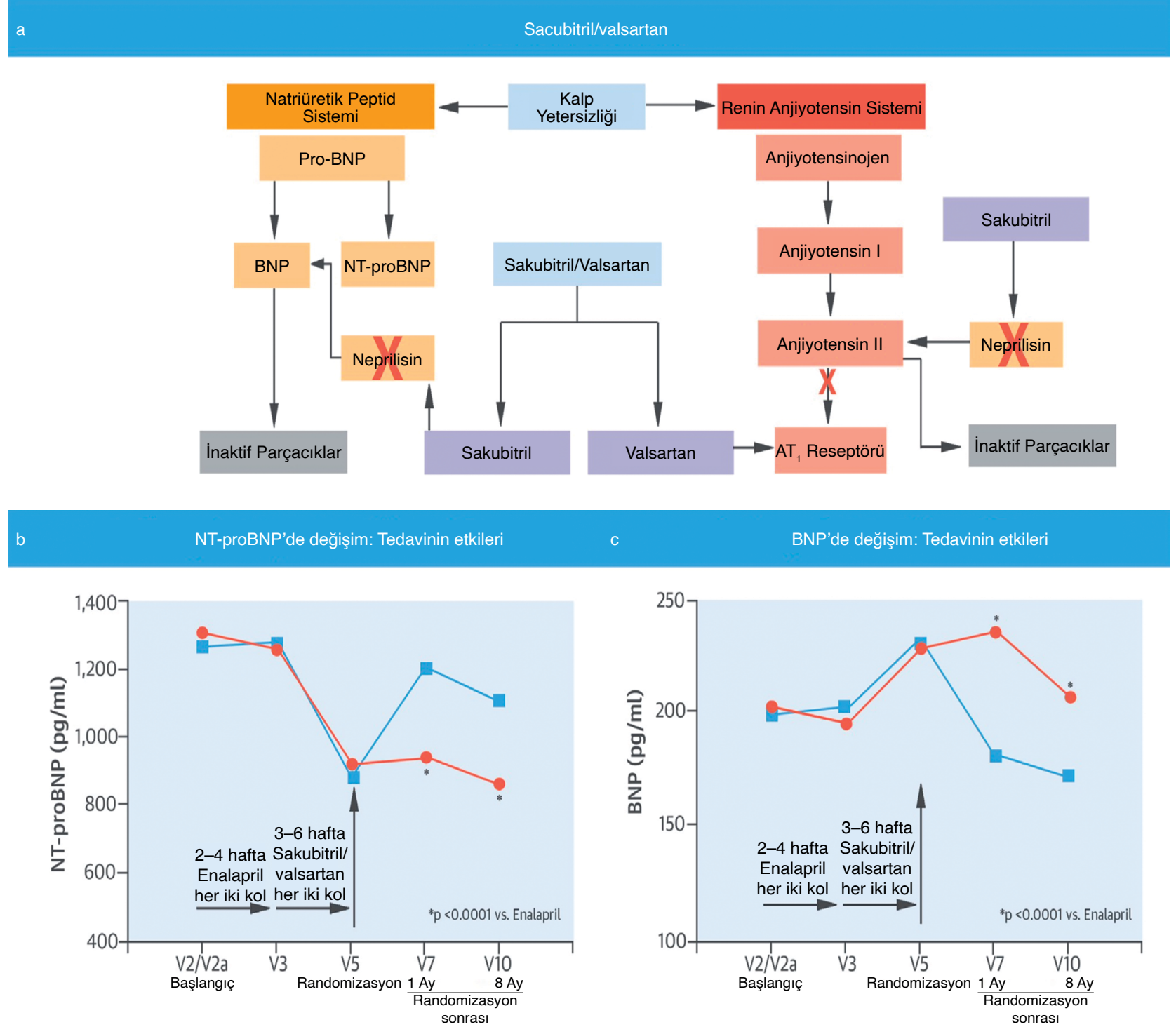

- Sakubitril/valsartan

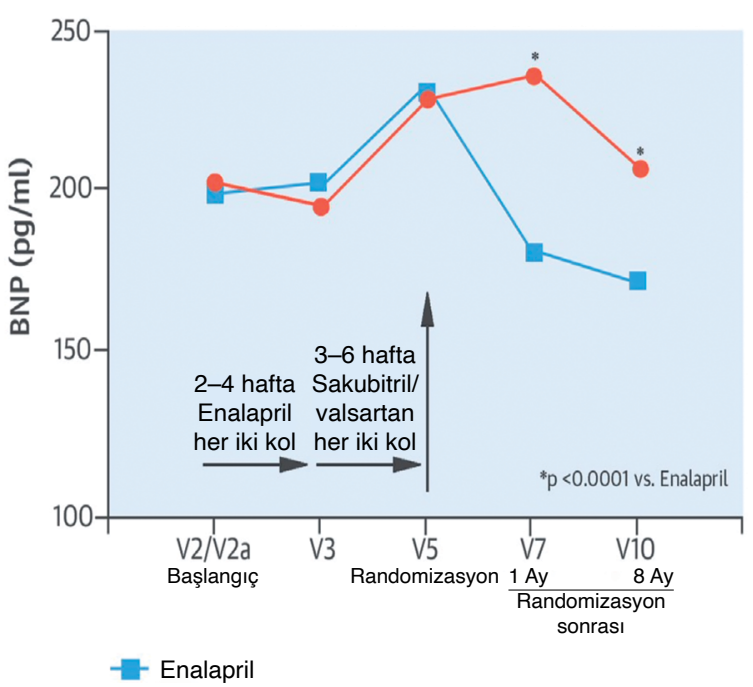

Şekil 1. Kalp yetmezliği hastalarında NT-proBNP değişikliklerinin prognostik etkileri.

Zile MR, Claggett BL, Prescott MF, McMurray JJ, Packer M, Rouleau JL, et al. Prognostic Implications of Changes in N-Terminal Pro-B-Type Natriuretic Peptide in Patients With Heart Failure. J Am Coll Cardiol 2016;68:2425-36.

$\mathrm{pg} / \mathrm{ml}$ olanların \%31 sakubitril-valsartan, \%17 ise enalapril kullanmaktaydı. Bunun yanında, NT-proBNP'si $\leq 1000 \mathrm{pg} / \mathrm{ml}$ olup 8. ayda NT-proBNP verisi olanlarda; sakubitril-valsartan kullanan hastaların \%74'ü NT-proBNP değeri $\leq 1000$ pg/ml kalırken bu oran enalapril kolunda \%59 olarak saptandı. Benzer sonuçlar NT-proBNP'si $\leq 750 \mathrm{pg} / \mathrm{ml}$ ve $\leq 500 \mathrm{pg} / \mathrm{ml}$ olanlarda da gözlendi. Yani NT-proBNP değerindeki belirgin azalmalar sakubitril-valsartan grubunda enalaprile oranla daha fazla gözlendi. NT-proBNP üzerindeki bu benzer diferansiyel tedavi (sakubitril-valsartan grubunda enalaprile kıyasla daha fazla görülme) etkisi yüzdesel, katogorik ve sürekli analizlerde de saptandı. Tüm analizlerde NT-proBNP'deki azalma ve bunun devamı sakubitril-valsartan grubunda enalaprile kıyasla daha fazla gözlendi.

Bazal NT-proBNP değeri her 2 tedavi kolunda da primer sonlanım noktalarının öngördürücüsü olurken sakubitril-valsartan ve enalaprilin tedavi etkilerini değiştirmemiştir. Tedavi ile bazal NT-proBNP değerindeki değişiklik ile primer sonlanım noktaları arasındaki ilişki arasında önemli interaksiyon bulunmamaktadır. Sakubitril-valsartan ile tedavi edilen hastalarda 1. ayda NT-proBNP değeri $\leq 1000$ pg/ 
Tablo 1. NTproBNP'de bazalden randomizasyon sonrası 1. aydaki değişiklik

\begin{tabular}{lcccccc}
\hline $\begin{array}{l}\text { 1.ayda NT-proBNP'deki } \\
\text { değişiklik }\end{array}$ & $\begin{array}{c}\text { Tüm hastalar } \\
(\mathrm{N}=1.942)\end{array}$ & $\begin{array}{c}\text { Sakubitril/valsartan } \\
(\mathrm{N}=971)\end{array}$ & $\begin{array}{c}\text { Enalapril } \\
(\mathrm{n}=971)\end{array}$ & \multicolumn{2}{c}{$\begin{array}{c}\text { Tedaviler } \\
\text { arası }\end{array}$} \\
\cline { 5 - 7 } & & & & $\mathrm{OR}$ & $95 \% \mathrm{Cl}$ & $\mathrm{p}$ \\
\hline Bazalde NT-proBNP $>1,000 \mathrm{pg} / \mathrm{ml}$ hastalar & $(\mathrm{n}=1.206)$ & $(\mathrm{n}=612)$ & $(\mathrm{n}=594)$ & & & \\
Yüksek-Yüksek & $918(76.1)$ & $425(69.4)$ & $493(83.0)$ & & & \\
Yüksek-Düşük & $288(23.9)$ & $187(30.6)$ & $101(17.0)$ & 2.15 & $1.63-2.83$ & $<0.001$ \\
Bazalde NT-proBNP $\leq 1,000 \mathrm{pg} / \mathrm{ml}$ hastalar & $(\mathrm{N}=736)$ & $(\mathrm{n}=359)$ & $(\mathrm{n}=377)$ & & & \\
Düşük-Yüksek & $124(16.8)$ & $38(10.6)$ & $86(22.8)$ & & & \\
Düşük-Düşük & $612(83.2)$ & $321(89.4)$ & $291(77.2)$ & 2.5 & $1.62-3.88$ & $<0.001$ \\
\hline
\end{tabular}

NT-proBNP: N-terminal pro-B-tipi natriüretik peptid; OR: Odds oranı.

ml olan hastalarda primer sonlanım noktaları azalması NT-proBNP değeri düşmeyen hastalara kıyasla $\% 56$ oranında azaldı. Benzer sonuçlar NT-proBNP'si $\leq 750 \mathrm{pg} / \mathrm{ml}$ ve $\leq 500 \mathrm{pg} / \mathrm{ml}$ olanlarda ve yüzdesel NTproBNP azalması olanlarda da gözlendi. Ayrıca, her 2 tedavi grubunda da bazalden 1. ay sonrası döneme kadar olan zamanda NT-proBNP düzeylerindeki değişikliklerin primer sonlanım noktaları üzerine anlamlı derecede öngördürücü olduğu saptanmıştır. Bu değerler sirasiyla enalapril kolunda NT-proBNP düzeyi 2 katına çıktığında HR 1.38 iken, sakubitril-valsartan kolunda ise 1.54 olarak gözlendi. Bunun yanında kategorik analiz yapıldığında, bazal değere göre 1. ayda NT-proBNP'deki azalma veya düşük olarak devamı sakubitril-valsartan grubunda enalaprile kıyasla daha sık görülmüştür (Tablo 1).

$\mathrm{Bu}$ çalışmanın ${ }^{[4]}$ sonunda düşük ejeksiyon fraksiyonlu KY hastalarında plazma NT-proBNP düzeylerindeki değişikliklerin kardiyovasküler ölüm ve KY nedeniyle hospitalizasyon sıklığındaki değişimle ilişkili olduğu, NT-proBNP düzeyindeki bazal seviyeye göre azalmaların daha düşük primer sonlanım noktalarına neden olduğu, sakubitril-valsartan kullanımının bazal NT-proBNP değerinde yaklaşık 2 kat azalma sağladığ1 gösterilmiştir. NT-proBNP ve primer sonlanım noktalarındaki risk değişimi tedavi gruplarından bağımsız olarak saptandı. Bu da NT-proBNP değişikliğinin prognostik değerinin sakubitril-valsartan ve enalapril alan gruplarda benzer olduğunu göstermiştir. Bazal NT-proBNP değerlerinin tümünde sakubitril-valsartanın enalaprile kıyasla primer olay sıklığını azalttığı saptandı. NT-proBNP'deki sürekli azalma sakubitril-valsartan grubunda enalaprile göre anlamlı olarak daha sık görüldü.

PIONEER-HF çalışmasında ${ }^{[9]}$ son 6 saat içerisinde hemodinamisi stabil, ejeksiyon fraksiyonu $<\% 40$ olan, NT-proBNP $>1600 \mathrm{pg} / \mathrm{ml}$ veya $\mathrm{BNP}>400 \mathrm{pg} / \mathrm{ml}$ olan akut kalp yetersizliği (AKY) hastaları sakubitrilvalsartan veya enalaprile randomize edildi. Çalışmanın sonunda NT-proBNP'de zaman ortalamalı azalma sakubitril-valsartan grubunda enalaprile göre daha fazla saptandı. Ayrıca çalışmada 4. ve 8. hafta sonunda NTproBNP seviyesinin bazale göre geometrik ortalamas1 sakubitril-valsartan grubunda 0.53 , enalapril grubunda 0.75, ve oransal değişme 0.71 olarak raporlandı (\%95 güven aralığ1, 0.63-0.81, p<0.0001). Sakubitril-valsartan grubunda 1. haftadan itibaren NT-proBNP'deki azalma enalapril grubuna göre anlamlı olarak daha fazla saptandı. Sakubitril-valsartan'ın enalaprile olan üstünlüğü çalışma alt gruplarında da tespit edildi. KY öyküsü olan ve olmayanlarda ve önceden ACEi/ARB kullanan veya kullanmayanlarda sakubitril/valsartan enalaprile üstün bulundu. Semptomatik ciddi hipotansiyon, hiperkalemi, renal fonksiyonların kötüleşmesi ve anjioödem her iki tedavi kolunda benzer bulundu. PIONEER-HF çalışmasının sonucunda özetle AKY hastalarında başlanan sakubitril/valsartan ile NT-proBNP'de k1sa sürede azalma sağlanmış olup nörohormonal biyobelirteçlerdeki azalma ile klinik sonlanımlar anlamlı derecede korelasyon göstermiştir. Ayrıca bu çalışma bize sakubitril-valsartanın AKY hastalarında ACEi/ARB kullanımı ve/veya KY öyküsünden bağımsız olarak hastaneden taburcu olmadan önce güvenle başlanmasının etkili ve güvenli olduğunu göstermiştir.

$\mathrm{Bu}$ çalışmalar 1şı̆̆ında hem akut hem de kronik düşük ejeksiyon fraksiyonlu KY hastalarında sakubitril-valsartan kullanımının bazal NT-proBNP değerlerinde enalaprile göre anlamlı azalma sağladığ 1 ve NTproBNP düzeylerinde sağlanan bu anlamlı azalmanın klinik sonlanımlarda sağlanan azalma ile ilişkili gerçekleştiği söylenebilir. Bu da sakubitril-valsartanın KY'de etkili ve güvenli olduğunu göstermektedir. 


\section{Kaynaklar}

1. Fonarow GC, Peacock WF, Phillips CO, Givertz MM, Lpatin M, ADHERE Scientific Committee and Investigators. Admission B-type natriuretic peptide levels and in-hospital mortality in acute decompensated heart failure. J Am Coll Cardiol 2007;49:1943-50.

2. Savarese G, Musella F, D'Amore C, Vassallo E, Losco T, Gambardella $\mathrm{F}$, et al. Changes of natriuretic peptides predict hospital admissions in patients with chronic heart failure: a meta-analysis. JACC Heart Fail 2014;2:148-58.

3. Masson S, Latini R, Anand IS, Barlera S, Angelici L, Vago T, et al. Prognostic value of changes in $\mathrm{N}$-terminal pro-brain natriuretic peptide in Val-HeFT (Valsartan Heart Failure Trial). J Am Coll Cardiol 2008;52:997-1003.

4. McMurray JJ, Packer M, Desai AS, Gong J, Lefkowitz MP, Rizkala $\mathrm{AR}$, et al. Dual angiotensin receptor and neprilysin inhibition as an alternative to angiotensin-converting enzyme inhibition in patients with chronic systolic heart failure: rationale for and design of the Prospective comparison of ARNI with ACEI to Determine Impact on Global Mortality and morbidity in Heart Failure trial (PARADIGM-HF). Eur J Heart Fail 2013;15:1062-73.

5. Hartmann F, Packer M, Coats AJ, Fowler MB, Krum H, Mohacsi P, et al. Prognostic impact of plasma N-terminal pro-brain natriuretic peptide in severe chronic congestive heart failure: a substudy of the Carvedilol Prospective Randomized Cumulative Survival (COPERNICUS) trial. Circulation 2004;110:1780-6.

6. Eurlings LW, van Pol PE, Kok WE, van Wijk S, Lodewijks-van der Bolt $\mathrm{C}$, Balk AH, et al. Management of chronic heart failure guided by individual $\mathrm{N}$-terminal pro-B-type natriuretic peptide targets: results of the PRIMA (Can PRo-brain-natriuretic peptide guided therapy of chronic heart failure IMprove heart fAilure morbidity and mortality?) study. J Am Coll Cardiol 2010;56:2090-100.

7. Troughton RW, Frampton CM, Yandle TG, Espiner EA, Nicholls MG, Richards AM. Treatment of heart failure guided by plasma aminoterminal brain natriuretic peptide (N-BNP) concentrations. Lancet 2000;355:1126-30.

8. Pfisterer M, Buser P, Rickli H, Gutmann M, Erne P, Rickenbacher P, et al. BNP-guided vs symptom-guided heart failure therapy: the Trial of Intensified vs Standard Medical Therapy in Elderly Patients With Congestive Heart Failure (TIME-CHF) randomized trial. JAMA 2009;301:383-92.

9. Velazquez EJ, Morrow DA, DeVore AD, Duffy CI, Ambrosy AP, McCague K, et al. Angiotensin-Neprilysin Inhibition in Acute Decompensated Heart Failure. N Engl J Med. 2019;380:539-48. 